\title{
OXIDATION OF AN ANTITUMOR DRUG ELLIPTICINE BY PEROXIDASES
}

\author{
Jitka Poljakováa $^{a}$ Kristina Forsterováa, Miroslav Šulc ${ }^{\mathrm{a}}$, Eva Frei ${ }^{\mathrm{b}}$, Marie Stiborováa \\ a Department of Biochemistry, Faculty of Science, Charles University, Albertov 2030, 12840 Prague 2, Czech Republic \\ ${ }^{b}$ Division of Molecular Toxicology, German Cancer Research Center, Im Neuenheimer Feld 280, 69120 Heidelberg, \\ Germany \\ e-mail: stiborov@natur.cuni.cz
}

Received: June 10, 2005; Accepted: September 25, 2005

Key words: Ellipticine/Anticancer drug/Peroxidase/Cytochrome P450/Oxidation

Ellipticine is a potent antineoplastic agent, whose mode of action is considered to be based mainly on DNA intercalation and/or inhibition of topoisomerase II. Since we found that ellipticine also forms the cytochrome P450 (CYP)-mediated covalent DNA adducts, this anticancer drug is considered to function as a pro-drug, whose pharmacological efficiency and/or genotoxic side effects are dependent on its enzymatic activation in target tissues. Here, we demonstrate that ellipticine is also oxidized by peroxidases, which are abundantly expressed in several target tumor tissues. Lactoperoxidase, myeloperoxidase and horseradish peroxidase were used as models. Peroxidases in the presence of hydrogen peroxide oxidize ellipticine to an ellipticine dimer and $N^{2}$-oxide of ellipticine as the major and minor metabolite, respectively. Inhibition of the peroxidase-mediated ellipticine oxidation by radical scavengers ascorbate, glutathione and NADH suggests a one-electron mechanism of the oxidation. The implication of the oxidation of ellipticine by peroxidases in its mechanism of action is discussed.

\section{INTRODUCTION}

Ellipticine (5,11-dimethyl-6H-pyrido[4,3-b]carbazole, Fig. 1), an alkaloid isolated from Apocyanaceae plants and several of its more soluble derivatives (9-hydroxyellipticine, 9-hydroxy- $N^{2}$-methylellipticinium, 9-chloro- $N^{2}$-methylellipticinium and 9-methoxy- $N^{2}$-methylellipticinium) exhibit promising results in the treatment of osteolytic breast cancer metastases, kidney sarcoma, tumors of brain and myeloblastic leukemia (for summary see ${ }^{1}$ ). The main reason for the interest in ellipticine and its derivatives for clinical purposes is their high efficiencies against several types of cancer, their rather limited toxic side effects and their complete lack of hematological toxicity ${ }^{2}$. Nevertheless, ellipticine is a potent mutagen. Most ellipticines are mutagenic to Salmonella typhimurium Ames tester strains, bacteriophage T4, Neurospora crassa, and mammalian cells and induce prophage lambda in Escherichia coli (for an overview see ${ }^{1}$ ).

Ellipticine is an antineoplastic agent, whose mode of action was considered to be based mainly on DNA intercalation and/or inhibition of topoisomerase II $\left(\right.$ ref. $^{3-7}$ ). Recently, we found another mode of the ellipticine action $^{1,8-10}$. We demonstrated that ellipticine covalently binds to DNA after being enzymatically activated. Using a panel of different human recombinant cytochrome $\mathrm{P} 450$ (CYP) enzymes, CYP3A4, 1A1 and 1B1, those enzymes expressed at higher levels in tumors sensitive to ellipticine (i.e. breast cancer) than in peritumoral tissues ${ }^{11-14}$, were found to be the most efficient CYP enzymes activat- ing ellipticine to form covalent DNA adducts in vitro ${ }^{1}$. Deoxyguanosine was identified to be the target for binding of two CYP-mediated ellipticine metabolites 13-hydroxyellipticine and the $N^{2}$-oxide of ellipticine ${ }^{9,10,15}$. The formation of these deoxyguanosine adducts by ellipticine was also detected in V79 Chinese hamster lung fibroblast cells transfected with human CYP3A4, 1A1 and $1 \mathrm{~A} 2^{8}$, in human breast adenocarcinoma MCF-7 cells ${ }^{16}$, in human HL-60 leukemia cells ${ }^{17}$ and in vivo in rats exposed to this anticancer drug ${ }^{10}$. On the basis of these data, ellipticine might be considered a drug, whose pharmacological efficiency and/or genotoxic side effects are dependent on its enzymatic activation in target tissues s $^{1,8-10,15-17}$.

While CYP enzymes are expressed in breast cancer, their levels are several orders of magnitude less in other ellipticine sensitive tumor cells. Peroxidases, abundant in some leukemia cells [i.e. myeloperoxidase (MPO) in HL-60 cells] might be candidates for ellipticine oxidation in these cells. Likewise, lactoperoxidase (LPO) that is<smiles>Cc1c2ccncc2c(C)c2c1[nH]c1ccccc12</smiles>

Fig. 1. Structure of ellipticine 
secreted by human mammary ductal epithelial cells into the breast duct ${ }^{18}$, might metabolized anticancer drugs. The present study was, therefore, undertaken to determine the capability of peroxidases to oxidize ellipticine.

\section{MATERIAL AND METHODS}

\section{Enzyme preparations}

Plant horseradish peroxidase (HRP; 300 purporogallin units/mg protein, 61 guaiacol units/mg protein), bovine lactoperoxidase (LPO; 117 purporogallin units/mg protein, 13 guaiacol units/mg protein), and human myeloperoxidase (MPO; 105 purporogallin units/mg protein, 11 guaiacol units/mg protein) were obtained from Sigma Chemical Co. (St. Louis, MO).

\section{Enzyme incubations}

Unless stated otherwise, incubation mixtures with peroxidases, in a final volume of $500 \mu \mathrm{l}$, consisted of $50 \mathrm{mM}$ potassium phosphate buffer ( $\mathrm{pH} 4.5$ - 8.4), 1-100 $\mu \mathrm{M}$ ellipticine (dissolved in $5 \mu \mathrm{l}$ methanol), and $1-20 \mu \mathrm{g}$ of peroxidase (LPO, HRP, or MPO). In incubations with these peroxidases, hydrogen peroxide was added as cofactor to a final concentration of 40-250 $\mu \mathrm{M}$. Control incubations were without peroxidases in the presence of hydrogen peroxide, or without hydrogen peroxide in the presence of peroxidases, or without ellipticine. Incubations with peroxidases were carried out at $37^{\circ} \mathrm{C}$ for $10-60 \mathrm{~min}$ All reactions were initiated by adding ellipticine dissolved in methanol (final concentration of methanol was $1 \%$ ). After incubations, $5 \mu \mathrm{l}$ of $1 \mathrm{mM}$ of salicylate or phenacetine in methanol was added as internal standards and the ellipticine metabolites were extracted twice with ethyl acetate $(2 \times 1 \mathrm{ml})$ from the incubations as described ${ }^{15}$. The extracts were evaporated under nitrogen and dissolved in $50 \mu \mathrm{l}$ of methanol. The ellipticine metabolites were separated by HPLC. The column used was a $5 \mu \mathrm{m}$ Ultrasphere ODS (Beckman, $4.6 \times 250 \mathrm{~mm}$ ) preceeded by a C-18 guard column. The eluents were; (i) $45 \%-90 \%$

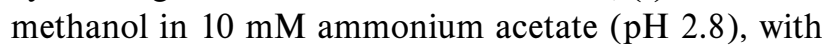
flow rate of $0.8 \mathrm{ml} / \mathrm{min}$, detection was at $296 \mathrm{~nm}$ (method A), and (ii) $64 \%$ methanol plus $36 \%$ of $5 \mathrm{mM}$ heptane sulfonic acid containing $32 \mathrm{mM}$ acetic acid in water with flow rate of $0.8 \mathrm{ml} / \mathrm{min}$, detection was at $296 \mathrm{~nm}$ (method B $)^{15}$. Recoveries of ellipticine metabolites were around $95 \%$ in the presence of enzymes without a peroxidase cofactor (hydrogen peroxide). One product peak with the retention time (r.t.) of $19.95 \mathrm{~min}$ and unconverted ellipticine with r.t. of 11.85 min were separated by HPLC using a method $\mathrm{A}$, while one product peak and residual ellipticine with r.t. of 11.2 and $12.9 \mathrm{~min}$, respectively, were separated with a method $B$.

To characterize ellipticine metabolites, fractions containing the metabolites eluting at $19.95 \min (\operatorname{method~A)}$ and $11.2 \mathrm{~min}$ (method B) were collected from multiple HPLC runs, concentrated on a speed-vac evaporator and analyzed by mass spectroscopy and/or co-chromatography on HPLC as described below.

\section{Mass Spectrometry}

ESI mass spectra were recorded on a Bruker Esquire quadrupole ion trap mass spectrometers (Bruker $\mathrm{GmbH}$, Bremen, Germany). Metabolites (final concentration $1 \mathrm{pmol} / \mu \mathrm{l})$ dissolved in methanol/water $(1: 1, \mathrm{v} / \mathrm{v})$ were continuously infused into the ion source via a linear syringe pump at a rate of $1 \mu \mathrm{l} / \mathrm{min}$ (Harvard Apparatus $22)$. The ionizer and ion transfer optics parameters of the ion trap were as follows: capillary voltage $-3500 \mathrm{~V}$, end plate $-3000 \mathrm{~V}$, capillary exit $100 \mathrm{~V}$, skimmer I $35 \mathrm{~V}$, skimmer II $7 \mathrm{~V}$, octopole I offset $8 \mathrm{~V}$, octopole II offset $8 \mathrm{~V}$, octopole r.f. $100 \mathrm{~V}$ peak-to-peak (pp), lens I -4 V, lens II $-45 \mathrm{~V}$. A flow of nitrogen (drying gas at $125^{\circ} \mathrm{C}$ ) was used to stabilize the spray. The spectra were scanned in the range $m / z 50-2000$ and the gating time was set to accumulate and trap $1 \times 10^{5}$ ions. Metabolites were also characterized by the MALDI-TOF (Matrix-Assisted Laser Desorption - Time of Flight) on the MALDI-TOF, Biflex (TM), Bruker-Daltonics.

\section{RESULTS}

When ellipticine was incubated with peroxidases (plant HRP, bovine LPO and human MPO were used models) in the presence of hydrogen peroxide, one major product peak, eluted at $19.95 \mathrm{~min}$, was observed by HPLC analysis using the solvent system A. Using the solvent system B for resolution of peroxidase-mediated ellipticine metabolites, another minor product peak, eluted with r.t. of $11.2 \mathrm{~min}$, was observed (chromatograms are not shown). On the basis of mass spectroscopy and co-chromatography with a synthetic standard, the structures of these two ellipticine metabolites were partially characterized.

In the MALDI-TOF and positive-ion electrospray mass-spectra, a major ellipticine metabolite, eluted with the system A, showed the protonated molecule at $\mathrm{m} / \mathrm{z} 490$ (Fig. 2), indicating the molecular mass of an ellipticine dimer. Although the molecular mass of this ellipticine dimer was clearly determined, its further structural characterization is currently being undertaken.

In the positive-ion electrospray mass-spectrum, the minor ellipticine metabolite eluting after $11.2 \mathrm{~min}$ with the solvent system $B$, showed the protonated molecule at $m / z 263.0$ (not shown), indicating the molecular mass of an oxygenated derivative of ellipticine. This minor ellipticine oxidation product was shown to be the $N^{2}$-oxide of ellipticine (5,11-dimethyl- $6 H$-pyrido[4,3-b]carbazole$N$-oxide), because it exhibited the same chromatographic properties on HPLC as the $N^{2}$-oxide of ellipticine standard prepared synthetically, by the reaction of ellipticine with 3-chloroperbenzoic acid ${ }^{15}$.

The rates of ellipticine oxidation by peroxidases used in the study were measured at $\mathrm{pH} \mathrm{4.5,} \mathrm{5.4,} \mathrm{6.4,} 7.4$ and 8.4. The highest velocity of the reaction was found at $\mathrm{pH}$ 6.4 (see Fig. 3 for HRP). The reaction is linear till $15 \mathrm{~min}$ of incubation (not shown).

While all three model peroxidases used in the study oxidize ellipticine to both two oxidation products, their 

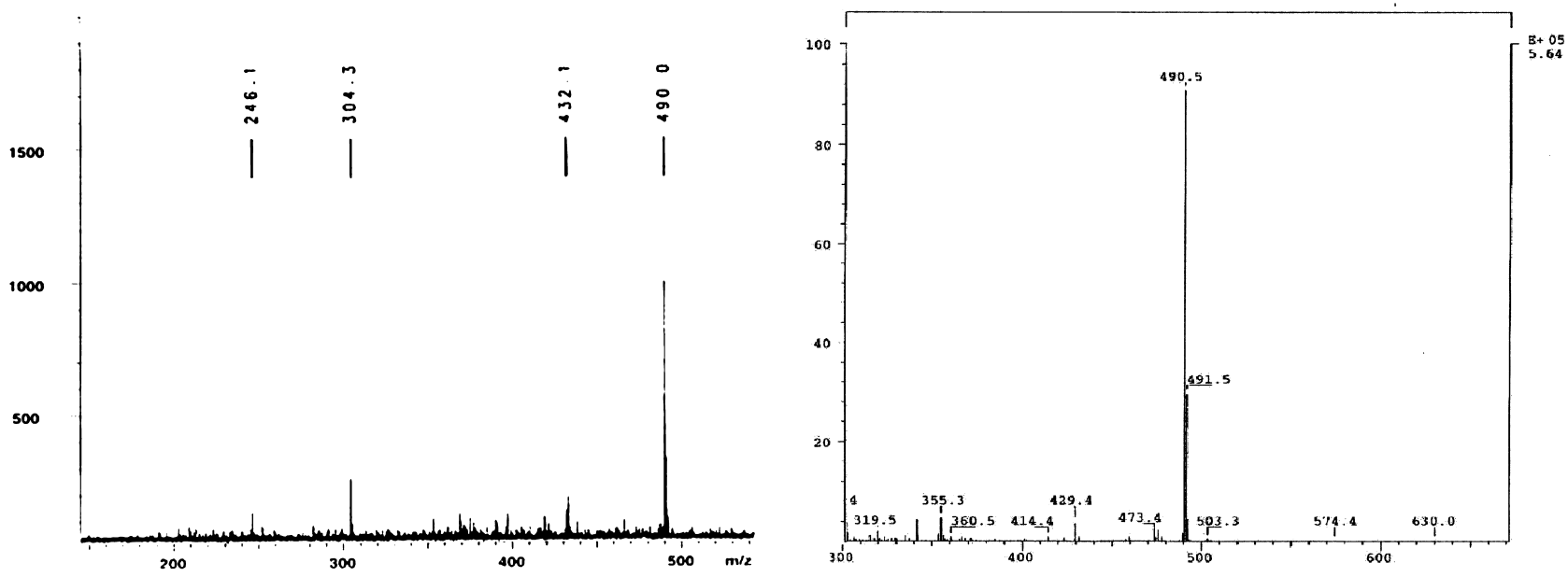

Fig. 2. Mass spectra [MALDI-TOF (A) and ESI (B)] of the major peroxidase-mediated ellipticine metabolite. The ion at $m / z 490$ indicates the molecular mass of an ellipticine dimer.

efficiencies to oxidize ellipticine differ considerably. LPO and MPO were less efficient in catalyzing oxidation of ellipticine than HRP. The kinetics of the two-substrate reaction of ellipticine oxidation with peroxidases in the presence of hydrogen peroxide was examined. The oxidation of ellipticine was measured in the reaction medium, which contained either of peroxidases tested in the study, hydrogen peroxide, and various concentrations of ellipticine. The reaction followed the hyperbolic kinetics for all peroxidases (measured as production of the ellipticine dimer). Under the conditions used and at $\mathrm{pH} 6.4$, the values of apparent Michaelis constants $\left(\mathrm{K}_{\mathrm{m}}\right)$ for ellipticine are of the same order for all peroxidases, while the value of the maximum rate for the ellipticine oxidation $\left(\mathrm{V}_{\max }\right)$ is highest for HRP and decreased for other peroxidases as follows: HRP > LPO > MPO (Table 1). The lower efficiency of LPO and MPO was, however, not specific for ellipticine, we also observed lower activity of these peroxidases with other substrates (i.e. guaiacol, $o$-anisidine) (results not shown).

The oxidation of ellipticine by peroxidases (assayed with HRP and LPO) is strongly inhibited by three physiological donors, NADH, glutathione and L-ascorbic

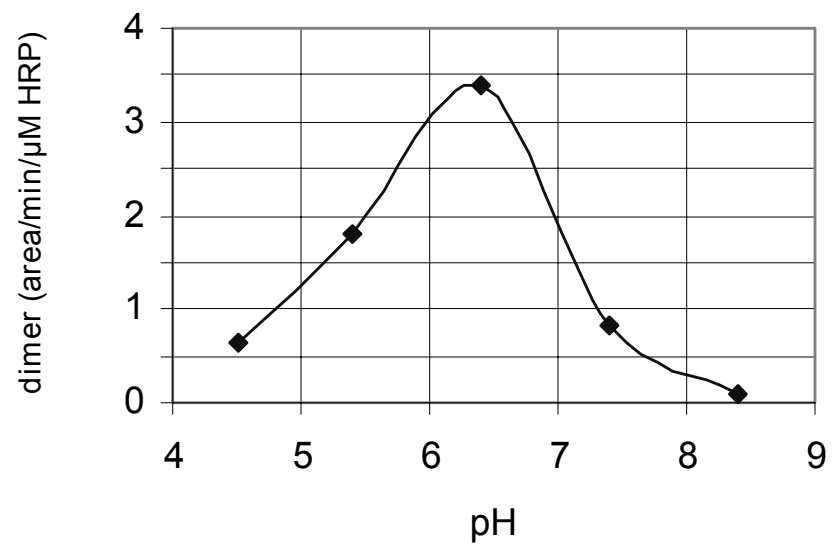

Fig. 3. pH optimum of ellipticine oxidation by HRP.

acid, which are known to be effective radical scavengers ${ }^{20}$ (Table 2). This finding indicates that the peroxidase-mediated oxidation of ellipticine proceeds via a conventional peroxidase reaction, namely, by a sequential one-electron oxidation of two molecules of elliptciine with peroxidase

Table 1. The values of Michaelis constant $\left(\mathrm{K}_{\mathrm{m}}\right)$ and maximum velocity $\left(\mathrm{V}_{\max }\right)$ for elliptine oxidation with peroxidases ${ }^{\mathrm{a}}$

\begin{tabular}{|c|c|c|}
\hline Peroxidase & $\mathrm{K}_{\mathrm{m}}(\mu \mathrm{M})^{\mathrm{b}}$ & $\mathrm{V}_{\max }(\mathrm{nmol} / \mathrm{min} \text { per } \mu \mathrm{g} \text { peroxidase })^{\mathrm{b}}$ \\
\hline HRP & $47.6 \pm 4.6^{\mathrm{c}}$ & $1.43 \pm 0.14$ \\
\hline LPO & $10.0 \pm 1.0$ & $0.25 \pm 0.02$ \\
\hline MPO & $12.0 \pm 1.2$ & $0.02 \pm 0.002$ \\
\hline
\end{tabular}

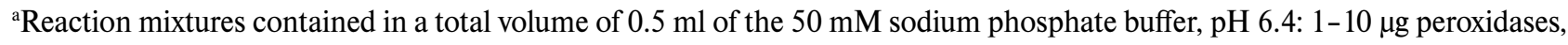
0.1-10 $\mu \mathrm{M}$ ellipticine and $0.25 \mathrm{mM} \mathrm{H}_{2} \mathrm{O}_{2}$. The incubation period was $15 \mathrm{~min}$. ${ }^{b}$ Reactions rates are expressed as amounts of the major ellipticine metabolite, the ellipticine dimer, production per $\mu$ g peroxidase per one minute. Kinetic analyses were carried out using the non-linear least-squares method as described ${ }^{19}$. ${ }^{\mathrm{C}}$ The values in the table are the means \pm standard errors (from three parallel experiments). 
Compounds I and II. It has already been found ${ }^{19,20}$ that none of these scavengers is a substrate of peroxidases under the conditions used in this work. Thus, the scavengers do not act as competitors with ellipticine for binding to the active centre of the enzymes. The effect of scavengers is therefore based on reduction of the radicals formed from ellipticine back to the parent compound.

In addition, the ellipticine oxidation by peroxidases is inhibited by nucleophiles such as DNA (Table 3). Likewise, deoxyguanosine 3'-monophosphate and deoxyadenosine 3'-monophosphate inhibit the ellipticine oxidation by $\sim 50 \%$ in the presence of $40 \mu \mathrm{g}$ of the deoxynucleotides. These results suggest that a primary formed ellipticine radical may bind to DNA or its deoxynucleotides.

\section{DISCUSSION}

The results of this study show that peroxidases such as bovine LPO, human MPO and plant HRP oxidize an anticancer drug ellipticine. During a radical-mechanism of the elllipticine oxidation by peroxidases, two ellipticine metabolites are generated. One of them, the minor one, is the metabolite that is also generated by ellipticine oxidation by human CYP enzymes, namely, $N^{2}$-oxide of ellipticine ${ }^{15}$. Such an $\mathrm{N}$-oxidation of ellipticine was found to be responsible for formation of one of the deoxyguanosine adducts in DNA generated by CYP enzymes from ellipticine ${ }^{15}$. While the exact structure of the major ellipticine metabolite formed by peroxidase, the ellipticine dimer, remains to be resolved, it seems that oxidation of ellipticine to this metabolite is crucial for formation of DNA adducts, too. It follows from the strong inhibition of the formation of this metabolite by DNA and/or deoxynucleotides. Indeed, the formation of DNA adducts from ellipticine by its oxidation by peroxidases was found

Table 2. Effect of radical scavengers on oxidation of ellipticine to the ellipticine dimer with HRP and LPO

\begin{tabular}{|c|c|c|c|}
\hline \multirow[t]{2}{*}{ Scavenger } & \multirow[t]{2}{*}{$\begin{array}{l}\text { Concentration } \\
(\mathrm{mM})\end{array}$} & \multicolumn{2}{|c|}{$\begin{array}{c}\text { Ellipticine oxidation }{ }^{\mathrm{b}} \\
\text { (nmol/min per } \mu \mathrm{g} \text { of peroxidase) }\end{array}$} \\
\hline & & LPO & HRP \\
\hline None & & $0.240 \pm 0.020^{c}$ & $1.300 \pm 0.130$ \\
\hline L-Ascorbic acid & 0.1 & $0.014 \pm 0.001$ & $\mathrm{ND}^{\mathrm{d}}$ \\
\hline & 0.5 & $\mathrm{ND}^{\mathrm{d}}$ & $\mathrm{ND}^{\mathrm{d}}$ \\
\hline NADH & 0.1 & $\mathrm{ND}^{\mathrm{d}}$ & $\mathrm{ND}^{\mathrm{d}}$ \\
\hline Glutathione & 0.1 & $0.043 \pm 0.005$ & $\mathrm{ND}^{\mathrm{d}}$ \\
\hline & 0.5 & $0.011 \pm 0.001$ & $\mathrm{ND}^{\mathrm{d}}$ \\
\hline
\end{tabular}

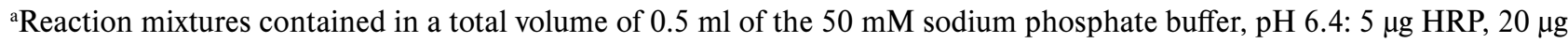
LPO, $50 \mu \mathrm{M}$ ellipticine and $40 \mu \mathrm{M} \mathrm{H}_{2} \mathrm{O}_{2}$ and scavengers at concentrations as shown. The incubation period was 15 min. ${ }^{b}$ Reactions rates are expressed as in Table 1 . ${ }^{\mathrm{c}}$ The values are the means \pm standard errors (from three parallel experiments). dNot detectable.

Table 3. Effect of calf-thymus DNA on oxidation of ellipticine to the ellipticine dimer with HRP and LPO

\begin{tabular}{|l|c|c|c|}
\hline \multirow{2}{*}{\begin{tabular}{c} 
Scavenger \\
\cline { 2 - 3 }
\end{tabular}} & $\begin{array}{c}\text { Concentration } \\
(\mu \mathrm{g})\end{array}$ & \multicolumn{2}{|c|}{$\begin{array}{c}\text { Ellipticine oxidation } \\
\text { (nmol/min per } \mu \mathrm{g} \text { of peroxidase) }\end{array}$} \\
\cline { 2 - 4 } None & & $0.240 \pm 0.020^{\mathrm{c}}$ & $1.300 \pm 0.130$ \\
DNA & 20 & $\mathrm{NM}^{\mathrm{d}}$ & $0.221 \pm 0.020$ \\
& 40 & $\mathrm{NM}^{\mathrm{d}}$ & $0.144 \pm 0.014$ \\
& 60 & $0.160 \pm 0.016$ & $0.082 \pm 0.008$ \\
& 80 & $0.137 \pm 0.014$ & $0.069 \pm 0.007$ \\
\hline
\end{tabular}

${ }^{a}$ Reaction mixtures contained in a total volume of $0.5 \mathrm{ml}$ of the $50 \mathrm{mM}$ sodium phosphate buffer, $\mathrm{pH}$ 6.4: $5 \mu \mathrm{g}$ HRP, $10 \mu \mathrm{g}$ LPO, $10 \mu \mathrm{M}$ ellipticine and $250 \mu \mathrm{M} \mathrm{H}_{2} \mathrm{O}_{2}$ and DNA at concentrations as shown. The incubation period was 15 min. ${ }^{\mathrm{b}}$ Reactions rates are expressed as in Table $1 .{ }^{\mathrm{c}}$ The values are the means \pm standard errors (from three parallel experiments). ${ }^{\mathrm{d}}$ Not measured. 
in our preliminary studies ${ }^{17,22}$. Nevertheless, the confirmation of the ellipticine-derived DNA adducts formation by ellipticine by such peroxidase-catalyzed reactions remains to be confirmed.

Although HRP might only serve as a model peroxidase, the findings that MPO and LPO are effective in ellipticine oxidation may be of greater significance. MPO is expressed in several human leukemia cells and is capable of metabolizing several xenobiotics, including drugs such as ellipticine, in these cells. Furthermore, LPO, besides MPO and CYP ${ }^{15}$, might be involved in oxidation of ellipticine in human mammary glands ${ }^{18}$. LPO is an enzyme present in milk, secreted by human mammary ductal epithelial cells into the breast ducts. Thus, like other lipophilic compounds ellipticine can possibly bioaccumulate in fatty tissues, such as the breast, and depending on the levels of activating enzymes present (e.g. LPO) ellipticine can be oxidized to intermediates modifying the key molecules such as DNA in this tissue. The importance of MPO and LPO in the oxidation of ellipticine is consistent with previous reports demonstrating that the enzymes metabolically activate a wide range of xenobiotics including drugs ${ }^{18}$. The detailed study concerning the modification of DNA molecules by ellipticine metabolites formed with peroxidases is under way in our laboratory.

\section{ACKNOWLEDGEMENT}

This work was supported by Ministry of Education of the Czech Republic (grant MSM 0021620808).

\section{REFERENCES}

1. Stiborová M, Bieler CA, Wiessler M, Frei E. (2001) The anticancer agent ellipticine on activation by cytochrome $\mathrm{P} 450$ forms covalent DNA adducts. Biochem Pharmacol 62, 1675-184.

2. Auclair C. (1987) Multimodal action of antitumor agents on DNA: The ellipticine series. Arch Biochem Biophys 259, 1-14.

3. Singh MP, Hill GC, Peoch D, Rayner, B, Inabach, JL, Lown JW. (1994) High-field NMR and restrained molecular modeling studies on a DNA heteroduplex containing a modified apurinic abasic site in the form of covalently linked 9-aminoellipticine. Biochemistry 33, 10271-85.

4. Chu Y, Hsu MT. (1992) Ellipticine increases the superhelical density of intracellular SV40 DNA by intercalation. Nucleic Acids Res 20, 4033-8.

5. Monnot M, Mauffret O, Simon V, Lescot E, Psaume B, Saucier JM, Charra M, Belehradek JJr, Fermandjian S. (1991) DNA-drug recognition and effects on topoisomerase II-mediated cytotoxicity. A three-mode binding model for ellipticine derivatives. J Biol Chem 25, 1820-9.

6. Fossé P, René B, Charra M, Paoletti C, Saucier JM. (1992) Stimulation of topoisomerase II-mediated DNA cleavage by ellipticine derivatives: structure-activity relationships. Mol Pharmacol $42,590-5$
7. Froelich-Ammon SJ, Patchan MW, Osheroff N, Thompson RB. (1995) Topoisomerase II binds to ellipticine in the absence or presence of DNA. Characterization of enzyme-drug interactions by fluorescence spectroscopy. J Biol Chem 270, 14998-5004.

8. Frei E, Bieler CA, Arlt VM, Wiessler M, Stiborová M. (2002) Covalent binding of the anticancer drug ellipticine to DNA in V79 cells transfected with human cytochrome P450 enzymes. Biochem Pharmacol 64, 289-95.

9. Stiborová M, Stiborová-Rupertová M, Bořek-Dohalská L, Wiessler M, Frei E. (2003) Rat microsomes activating the anticancer drug ellipticine to species covalently binding to deoxyguanosine in DNA are a suitable model mimicking ellipticine bioactivation in humans. Chem Res Toxicol 16, 38-47.

10. Stiborová M, Breuer A, Aimová D, Stiborová-Rupertová M, Wiessler M, Frei E. (2003) DNA adduct formation by the anticancer drug ellipticine in rats determined by ${ }^{32} \mathrm{P}$-postlabeling. Int J Cancer 107, 885-90.

11. Murray GI., Weaver RJ, Paterson PJ, Ewen SW, Melvin WT, Burke MD. (1993) Expression of xenobiotic metabolizing enzymes in breast cancer. J Pathol 169, 347-53.

12. Murray GI, Melvin WT, Burke M.(1995) Cytochrome P450 expression in tumors. J Pathol 3, 147-52

13. Patterson LH, McKeown SR, Robson T, Gallagher R, Raleigh SM, Orr S. (1999) Antitumor prodrug development using cytochrome P450 (CYP) mediated activation. Anti-Cancer Drug Design 14, 473-86.

14. El-Rayes BF, Ali S, Heilbrun LK, Lababidi S, Bouwman S, Vischer D, Philip PA. (2003) Cytochrome P450 and glutathione transferase expression in human breast cancer. Clin Cancer Res 9, 1705-9.

15. Stiborová M, Sejbal J, Bořek-Dohalská L, Aimová D, Poljaková J, Forsterová K, Rupertová M, Wiesner J, Hudeček J, Wiessler M, Frei E. (2004) The anticancer drug ellipticine forms covalent DNA adducts, mediated by human cytochromes $\mathrm{P} 450$, through metabolism to 13-hydroxyellipticine and ellipticine $N^{2}$-oxide. Cancer Res 6, 8374-80.

16. Bořek-Dohalská L, Frei E, Stiborová M. (2004) DNA adduct formation by the anticancer drug ellipticine and its hydroxy derivatives in human breast adenocarcinoma $\mathrm{MCF}-7$ cells. Collect Czech Chem Commun 69, 603-15.

17. Poljaková J, Stiborová M. (2004) Peroxidase-mediated ellipticineDNA adduct formation explains the selective efficiency of this anticancer drug against breast cancer and leukemia. Chem Listy 98, 298.

18. Williams JA, Phillips DH. (2000) Mammary expression of xenobiotic metabolizing enzymes and their potential role in breast cancer. Cancer Res 60, 4667-77.

19. Stiborová M., Hansíková H, Schmeiser HH, Frei. E. (1997) An investigation of the metabolism of $N$-nitrosodimethylamine and $N$-nitrosomethylaniline by horseradish peroxidase in vitro. Gen Physiol Biophys 16, 285-97.

20. Stiborová M, Frei E, Schmeiser HH, Wiessler M, Hradec J. (1990) Mechanism of formation and ${ }^{32} \mathrm{P}$-postlabelling of DNA adducts derived from peroxidative activation of carcinogenic non-aminoazo dye 1-phenylazo-2-hydroxynaphthalene (Sudan I). Carcinogenesis $11,1843-8$

21. Stiborová M, Mikšanová M, Martínek V, Frei E. (2000) Heme peroxidases: structure, function, mechanism and involvement in activation of carcinogens. A review. Collect Czech Chem Commun 65, 297-325.

22. Frei E, Borek-Dohalska L, Wiessler M, Stiborova M. (2001) Ellipticine forms covalent DNA adducts in rats with properties similar to adducts formed in vitro after activation by cytochrome P450 or peroxidases. Proc Am Assoc Cancer Res 42, 252. 